\title{
A comparison of experimental methods for measuring water permeability of porous building rocks
}

\author{
S. Galvan ${ }^{\mathrm{a}}$, C. Pla ${ }^{\mathrm{a}, \mathrm{b}}$, N. Cueto ${ }^{\mathrm{a}, \mathrm{b}}$, J. Martínez-Martínez ${ }^{\mathrm{a}, \mathrm{b}}$, M.A. García-del-Cura ${ }^{\mathrm{a}, \mathrm{c}}$, D. Benavente ${ }^{\mathrm{a}, \mathrm{b}} \bowtie$ \\ a. LPA, Unidad Asociada UA-CSIC (Alicante, Spain) \\ b. Universidad de Alicante (Alicante, Spain) \\ c. Instituto de Geociencias IGEO, CSIC, UCM (Madrid, Spain) \\ $\triangle$ david.benavente@ua.es
}

\begin{abstract}
This paper compares different experimental methods for measuring water permeability in 17 different porous building rocks. Both commercial apparatus and specially made designed permeameters are used for characterising intrinsic permeability and hydraulic conductivity, $\mathrm{k}$, of rocks in the range of $10^{-12}$ to $10^{-4} \mathrm{~m} / \mathrm{s}$ $\left(\sim 10^{-19}-10^{-11} \mathrm{~m}^{2}\right.$ or $\left.\sim 10^{-4}-10^{4} \mathrm{mD}\right)$. We use both falling head and constant head permeameter methods including the triaxial and modified triaxial tests and a classical constant head permeameter.

Results showed that for very low and low permeability samples $\left(\mathrm{k}<10^{-6} \mathrm{~m} / \mathrm{s}\right)$, triaxial conditions were found the most accurate procedures and they provided similar or slightly lower permeability values than constant and falling head methods. The latter techniques were highly recommended for permeable and high permeable porous building materials. Water permeability values were also linked to effective porosity and interpreted in terms of interparticle and vugs porosity. Finally, some modifications in the apparatus and procedures were carried out in order to assess water permeability in soft materials, which involve the use of non-saturated samples.
\end{abstract}

KEYWORDS: Permeability; Water transport properties; Ornamental stone; Sedimentary rocks

Citation / Citar como: Galvan, S.; Pla, C.; Cueto, N.; Martínez-Martínez, J.; García-del-Cura, M.A.; Benavente, D. (2014) A comparison of experimental methods for measuring water permeability of porous building rocks. Mater. Construcc. 64 [315], e028 http://dx.doi.org/10.3989/mc.2014.06213.

RESUMEN: Comparación de métodos experimentales para medir la permeabilidad al agua en rocas de construcción porosas. Se comparan diferentes métodos experimentales para la medida de la permeabilidad al agua en rocas porosas usadas como material de construcción. Se usaron diferentes permeabilímetros, (comerciales y desarrollados específicamente) empleando los métodos triaxial, triaxial modificado, carga constante y carga variable.

Se caracterizó la permeabilidad intrínseca y conductividad hidráulica, $\mathrm{k}$, con valores que varían desde $10^{-12}$ a $10^{-4} \mathrm{~m} / \mathrm{s}\left(\sim 10^{-19}-10^{-11} \mathrm{~m}^{2}\right.$ or $\left.\sim 10^{-4}-10^{4} \mathrm{mD}\right)$. Para muestras poco y muy poco permeables el ensayo con célula triaxial fue el mas reproducible. Los ensayos de carga constante son muy recomendables para rocas porosas de construcción permeables y muy permeables. Además, se definen los parámetros experimentales más apropiados para caracterizar la permeabilidad de rocas de construcción. La permeabilidad al agua se relaciona con la porosidad efectiva y se interpreta en términos de porosidad tipo interpartícula y vugs. Finalmente, se modificaron los equipos y procedimientos para poder estimar la permeabilidad en materiales blandos.

PALABRAS CLAVE: Permeabilidad; Propiedades de transporte de agua; Roca ornamental; Rocas sedimentarias

Copyright: (C) 2014 CSIC. This is an open-access article distributed under the terms of the Creative Commons Attribution-Non Commercial (by-nc) Spain 3.0 License. 


\section{INTRODUCTION}

Permeability measures the material's ability to transmit fluids and can be termed in different ways depending on the field. Permeability, coefficient of permeability or intrinsic permeability depends only on the pore structure of the material, it is independent of fluid properties and it is based in the Darcy's equation. Permeability has units with dimensions of area $\left(\mathrm{m}^{2}\right)$. A practical unit for permeability is the darcy (D), or more commonly the millidarcy $(\mathrm{mD})\left(1 \mathrm{D} \sim 10^{-12} \mathrm{~m}^{2}\right)$. Hydraulic conductivity is usually referred to permeability or coefficient of permeability and it is related to intrinsic permeability (pore structure) and to the properties of the fluid (dynamic viscosity of the fluid and specific gravity of the fluid). Hydraulic conductivity has units with dimensions of length per time or speed (e.g., m/s, cm/day or ft/day). Thus, for pure water at $20^{\circ} \mathrm{C}, 1 \mathrm{D} \sim 10^{-12} \mathrm{~m}^{2} \sim 10^{-5} \mathrm{~m} / \mathrm{s}$. In this paper, we use the term water permeability for both intrinsic permeability and hydraulic conductivity, so that, a special attention to permeability units should be given in order to understand what parameter is mentioned.

Saturated water permeability of construction and building materials, including stone, concrete and bricks, is seldom the dominant transport mechanism in real situations. Real mass transfer takes place by two-phase flow in which the vapour component is dominant. Nevertheless, there are particular cases where water permeability is the predominant transport mechanism. For instance, stagnant water due to rains may affect ancient and modern buildings and monuments such as fountains, terraces and basements $(1,2)$. Other examples can be found in subsurface quarries of building stones (3) or ancient hydraulic constructions, such as bridges, aqueducts, dams or canals (4-6).

Saturated permeability has been of great interest since it quantifies the connectivity of the pore structure and assesses the durability of construction and building material. The influence of pore structure and water transfer on durability can greatly vary depending on the nature of the building rock. Thus, porous materials with low porosity values $(<10 \%)$ have low water transfer coefficients, and are also more durable than highly porous rocks. For example, dense oolitic and microcrystalline limestones, granites or marbles present low porosity and permeability, and have excellent durability properties (7). However, porous stones with effective porosity values higher than $10 \%$, small pores and low water transport coefficient values, indicate a high susceptibility to salt weathering decay $(8,9)$. It is generally accepted that crystallization of salts and ice is a major deterioration mechanism in porous building stones. The effectiveness of crystallization stress generated by salt and ice growth may be considered for the pore throat size interval between 0.1 and $10 \mu \mathrm{m}$. Thus, large pores do not contribute significantly to salt and ice weathering since they consume the high supersaturations caused by the growth of large crystals and, therefore, do not produce sufficient stress to damage these building stones (9). This effect explains why built heritage stones with large pores, as some travertines or tufas and lumachellas are more resistant to salt and ice deterioration and present higher permeability values than porous stones with thin pores as some sandstones, dolostones or calcarenites.

Furthermore, air surface permeability has been used to estimate salt deterioration in both lab and monuments studies $(10,11)$. The variation of surface permeability is then related not only to the presence of moisture or salts, but also to pore structure variation by different decay mechanisms.

Most common existing standard tests to measure water permeability can be divided into two different groups, depending on the head loss or inflow pressure variation/constancy. Constant head methods maintain constant the hydraulic pressure or head whereas inflow pressure decreases due to variation of water column in falling head methods.

There is a lack of water permeability standard tests of building stones. Most standard tests of rock permeability use flowing air instead of water (for instance, ASTM D4525-90 (12)). Water permeability standard tests were found for soil issues, such as ASTM D6035-02 (13), ASTM D6527-00 (14) and UNE 103403 (15), or concrete and mortars, including UNE 83310 (16) and RILEM 1980 (17). Otherwise, some standard tests (for instance, ASTM 5856-95 (18)) can request a constant rate of flow, so that head loss across the sample has to be measured.

The aim of this paper is to compare different experimental methods for measuring water permeability of porous building rocks. Laboratory methods are based and adapted from standard tests used in cementitious materials and soil sciences. For this purpose, both commercial apparatus and specially made designed permeameters are used for characterizing stone permeability in the range of $\sim 10^{-12}-10^{-4} \mathrm{~m} / \mathrm{s} ; \sim 10^{-19}-10^{-11} \mathrm{~m}^{2}$; or $\sim 10^{-4}-10^{4} \mathrm{mD}$.

Finally, some modifications of the apparatus and procedures are carried out in order to assess water permeability in soft materials, such as soft rocks, ancient and repair mortars, etc. The interest of measuring water permeability in this kind of porous rocks is increasing in the field of built heritage, where stones may be weathered; $\mathrm{CO}_{2}$ storage, etc. Soft materials may be altered in contact with water, compromising sample preparation 
and permeability testing. Thus, if sample loses material, it can damage the permeameter and/ or produce inaccurate measurements. Researches tend to characterise the permeability using gas permeameters, which are usually more expensive. Nevertheless, real water flow value is sometimes required.

\section{EXPERIMENTAL PROCEDURES}

\subsection{Materials}

In this study, 17 samples of porous stones have been chosen for their different petrophysical and petrographic characteristics (Figure 1). These stones are used as building materials or found in the Spanish built heritage. The stones tested correspond to four groups of sedimentary rocks: biocalcarenites $(\mathrm{C})$, travertines $(\mathrm{T})$, allochem limestones (L) and silica-cemented sandstones (S). Next, a brief description of the different groups is shown:

The studied biocalcarenites are carbonate sandstones with calcite cement, variable amount of terrigenous components and fossils (mainly foraminifera) and interparticle porosity. $\mathrm{C} 1$ is a variety of the Piedra de Úbeda (19), which contains foramanifera and bivalve fragments and quartz, feldspar and dolostone grains. The interparticle porosity is relatively well cemented by rim and blocky calcitic cements. C2, C3 and C4 are four varieties of the Piedra Bateig calcarenite. These are well-sorted biocalcarenites and contain foraminifera and quartz, feldspar, mica and dolomite grains (20-22). C5 shows bioclasts larger than the rest of the studied biocalcarenites and is constituted by bryozoans, red algae, molluscs and echinoderms. Other detrital components are quartz, dolostones and feldspars (20). C6 is composed by foraminifera, quartz, feldspars and mica grains (20).

The studied travertines are quarried in Albox (Almería province, SE of Spain) and are commercialised as Travertino Oro or Yellow Gold Travertine. Currently, this yellowish-brown travertine is mainly used as cladding and paving. The studied travertines present different structural (mesofeatures) and textural (microfeatures) characteristics (23). T7 presents a banded-massive structure with low porosity values (mainly intercrystalline porosity). T8 shows a porous banded structure with fenestral and vug macroporosity, which provide a structural anisotropy. T8 also has interparticle and intercrystalline porosity. Permeability measurements were carried out in the perpendicular direction to the bedding. T9 presents a banded-massive structure with low porosity values (mainly intercrystalline porosity). T9 shows some separated fenestral and
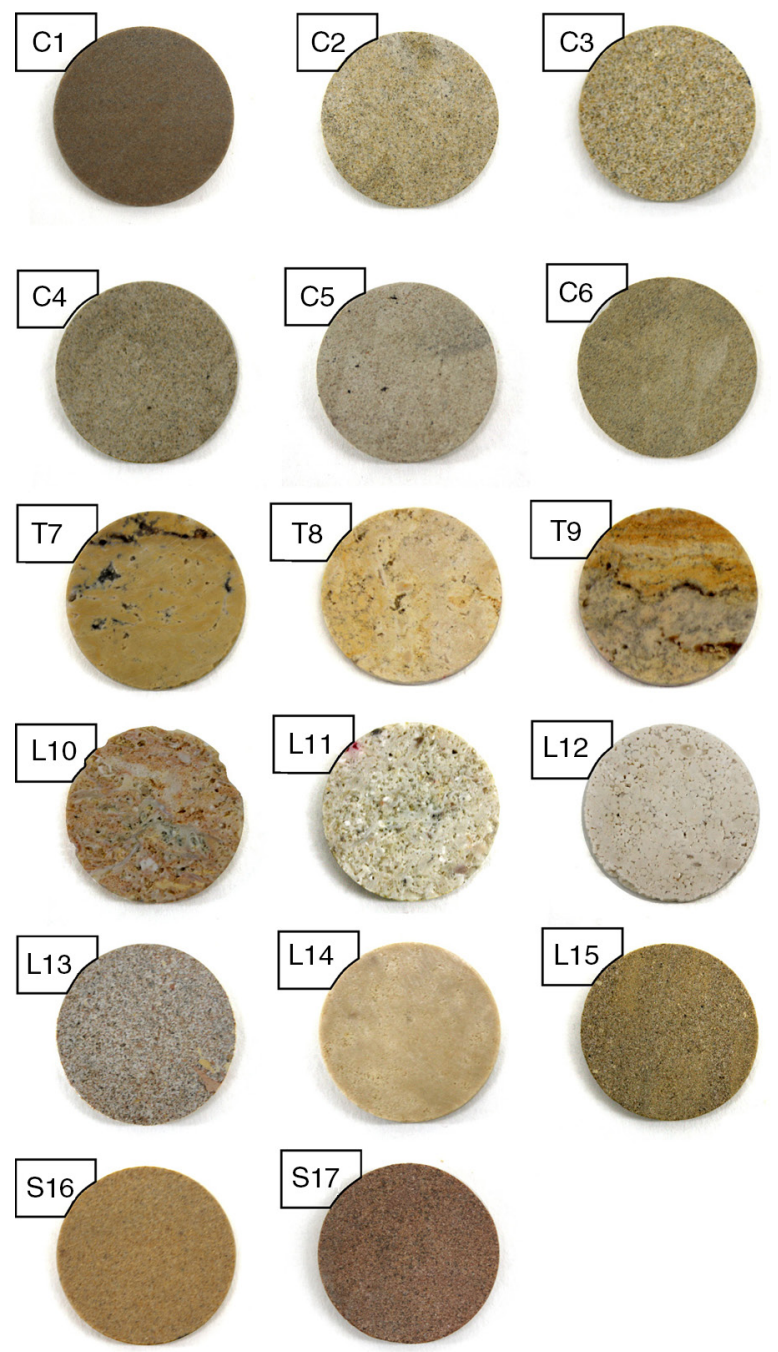

FIGURE 1. Image of the studied samples. C: biocalcarenites. T: travertines. L: allochem limestones. S: silica cement sandstones.

vug macroporosity, so these macropores are interconnected only through intercrystalline porosity. Permeability measurements were carried out in the parallel direction to the bedding.

Allochem limestones show a wide range in the size and type of allochems. These limestones mainly have interparticle porosity. L10 and L11 are detrital limestones (biorrudites) composed of large allochem grains (mainly bivalves, bryozoans and red algae) (20). L12 is an oolitic limestone (oosparite) where oolites are densely packed and poor sorted (24). L13 is a limestone with foraminifera and micrite and contains some iron oxides and lime clasts. L14 is a biomicrite composed of oriented fragments of fossils (mainly ostracods and molluscs), which consequently, provide a structural anisotropy to the rock. Permeability measurements were carried out in the perpendicular 
direction to the bedding (25). L15 is a well-sorted sandstone consisting of mainly dolomite and calcite grains. The ortochem is mesocrystalline calcite cement (8).

Quartz-rich sandstones are well-sorted sandstones and cemented by secondary (authigenic) quartz. S16 is mainly composed of monocrystalline quartz grains (20). S17 is a fine-grained arkose constituted by quartz, feldspars (potassiumfeldspar and plagioclases) and chert. Accessory minerals, such as muscovite and tourmaline, can be also observed.

\subsection{Effective porosity}

Effective porosity, $\varnothing_{v s}$, defined as the ratio of the volume of connected voids to total stone volume and expressed as a percentage, was performed applying vacuum saturation porosity test on cylindrical samples in the form of $3 \mathrm{~cm}$ in diameter and $6 \mathrm{~cm}$ in height.

Dried samples were weighed and placed in a vacuum chamber at $20 \pm 7$ mbar pressure controlled by a vacuum manometer. Three 24-hour cycles were carried out for each. Firstly, any trapped air was eliminated from the porous systems. Secondly, distilled water was slowly introduced until the samples were completely covered. Thirdly, atmospheric pressure was re-established in order to avoid porous system dilatation. Then the saturated and immersed weight of each sample was recorded.

\subsection{Permeability methods}

Permeability measurements were performed in the same cylindrical samples as those performed in the effective porosity test. Permeability was measured on water saturated samples. Thus, after effective porosity characterisation, vacuum saturated samples were then tested. Finally, some non-saturated samples were saturated during the inflow of water and permeability was calculated when steady-state was reached (water flow rate at inflow equals to water outflow rate). In this paper, we use three constant head methods (triaxial test, modified triaxial test and classical constant head permeameter) and two failing head methods. Four measurements were performed in each sample. The maximum duration of each experiment was 24 hours in order to assess what method was more adequate for relatively fast permeability characterisations.

\subsection{Triaxial method}

Permeability tests were carried out in a triaxial device (Figure 2) with an automatic pressure system using the steady-state method. Pressure and volume changes were regulated by a pressure/volume
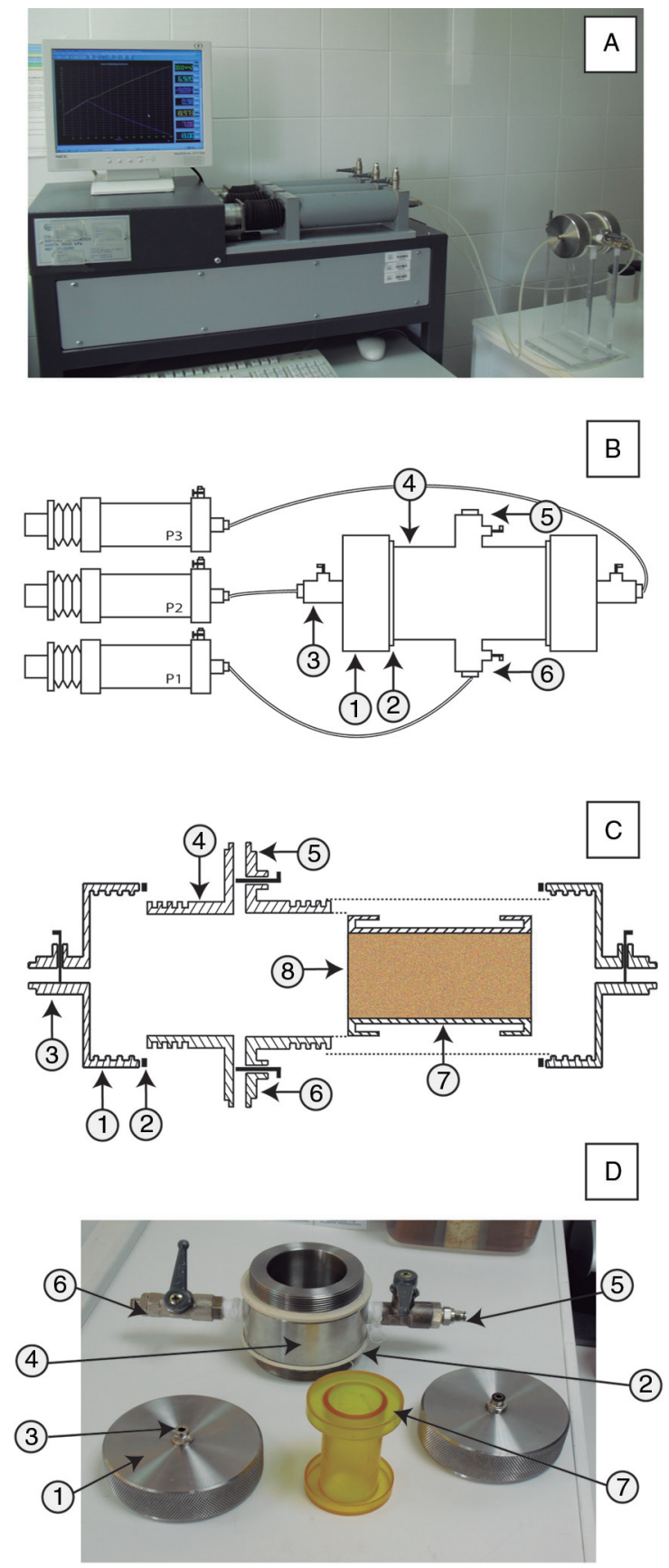

FIgurE 2. Triaxial method. Schematic diagram of triaxial cell (A). Triaxial method apparatus. (B). Pressure maintainers. P1: Confining pressure. P2: Inflow pressure. P3: Outflow pressure. In the TM, outflow pressure is fixed in the end caps and outflow water circulates from equipment. MTM procedure uses the atmospheric pressure as outflow pressure. (C). Triaxial Cell:

1. Movable top-end plate. 2. Rubber joint. 3. Inflow-Outflow pressure entrance. 4. Steel body. 5. Open/close valve. 6. Confining pressure entrance. 7. Nitrile rubber sleeve. 8. Sample. (D). Triaxial cell pieces.

controller, with an accuracy of $0.1 \%$ for pressure measurements and $0.5 \%$ over $100 \mathrm{~cm}^{3}$ for volume changes. Volume changes and confining and 
differential pressures were defined and controlled using the Mecasoft code (see details in (8)).

In the triaxial method, water flows through a confined sample from driven, entrance or inflow pressure, $\mathrm{P}_{1}$, to exit or outflow pressure, $\mathrm{P}_{0}$. Two variations of the triaxial method were performed modifying the outflow pressure, which were termed as TM (triaxial method) and MTM (modified triaxial method). In the TM, outflow pressure is fixed in the end caps and outflow water circulates from equipment. MTM procedure uses the atmospheric pressure as outflow pressure, so that water does not remain in the permeameter. The latter can be adequate for testing soft material, in which loss material can be probable.

The confining, inflow and outflow pressures in the TM were respectively of 13 bar, 7 and 3 bars. These experimental conditions were used for all the tested samples. However, in the MTM, the inflow pressure was adjustable to each porous stone in order to reach reproducible results. The confining pressure was 13 bars whereas the outflow pressure was the atmospheric pressure.

In general, low permeable rocks request higher inflow pressure. Thus, an inflow pressure of 10 bar was used for testing C1, L12, L13 and L17 samples; $\mathrm{P}_{1}=7$ bars for testing $\mathrm{C} 2, \mathrm{C} 3, \mathrm{C} 4, \mathrm{C} 5, \mathrm{C} 6$ and $\mathrm{L} 16$ samples; and $\mathrm{P}_{1}=5$ bars for T7, T8, T9 and L14 samples. The confining pressure (1.3 $\mathrm{MPa})$ was lower than the unconfined compressive strength, which ranges between 10-70 MPa for the studied samples (19-25). This value of confining pressure does not modify the pore structure of rocks, and consequently, neither the rock permeability, as well as it does not create mechanical damage on the tested rock.

Samples were placed in a nitrile rubber sleeve, to which the confining pressure is applied. Thus, samples were not laterally sealed with PTFE and/ or with a shrinkable sleeve, as they were performed at constant and falling head permeability methods.

Water permeability (intrinsic permeability), $\mathrm{k}\left(\mathrm{m}^{2}\right)$, was determined according to Darcy's Equation [1] when the steady-state flow was attained:

$$
k=\frac{\eta Q L}{A \Delta p}
$$

where $\eta$ is the water viscosity $\mathrm{kg} /(\mathrm{ms}), \mathrm{Q}\left(\mathrm{m}^{3} / \mathrm{s}\right)$ is the volumetric flow-rate of water, $\mathrm{L}(\mathrm{m})$ is the length of the sample, $\mathrm{A}\left(\mathrm{m}^{2}\right)$ is the cross-sectional area of the sample perpendicular to the direction of flow and $\Delta \mathrm{P}=\mathrm{P} 1-\mathrm{P} 0(\mathrm{~Pa})$ is the pressure gradient.

A laminar (steady-state) flow rate with a constant pressure is achieved when the X-Y plot is a straight line. This equipment provides very accurate permeability measurements from values $\sim 10^{-11}-10^{-5} \mathrm{~m} / \mathrm{s}$ or $\sim 10^{-18}-10^{-12} \mathrm{~m}^{2}$.

\subsection{Constant head method}

The apparatus (Figure 3) consisted of a tank with overflow that kept the water level constant during the whole test. This tank was fed by a water tap. The entire assembly was attached to the wall. The sample was placed below the tank connected by a PVC tube using a PVC cap. This connection mechanism and the method of preparing the sample were similar to that used in the falling head permeameter ( 8 tubes permeameter). To let the water exit from the permeameter and pass through the sample there was a two-arm valve: one of the arms was used to purge the air before beginning the test and the other was used to fit the sample.

The sample was sealed, as described in the falling head method, covering its lateral surface with a single length of PTFE first. Over the sample, it was placed a heat shrinkable sleeve that is shrank with hot air to minimize its diameter. The neck of the prepared sample was narrower than the body so the sample fitted the PVC cap perfectly.

The water permeability or hydraulic conductivity, $\mathrm{k}(\mathrm{m} / \mathrm{s})$, of the sample is determined from Eq. [2]:

$$
k=\frac{V L}{A \Delta h t}
$$

where $V\left(\mathrm{~m}^{3}\right)$ is the volume of water accumulated in the container during a time (t) interval (s), $L$ is the length of the sample (m), $A$ is the cross sectional area of the sample $\left(\mathrm{m}^{2}\right)$ and $\Delta h$ is the height between the level of water in the tank and the sample $(\mathrm{m})$, that means the height of the water column above the sample.

\subsection{Falling head method}

In the present study, two variations of falling head methods have been tested. The first method comprised a panel of 8 tubes (Figure 4), typically used in commercial soil testing (for example, combination permeameter). Therefore, in this method, multiple samples can be tested simultaneously. The second method (Figure 5) consisted of a single graduated cylinder to test one specimen.

The multiple tubes permeameter had 8 crystal tubes of $100 \mathrm{~cm}$ height and $9 \mathrm{~mm}$ diameter attached for wall mounting. The standpipe was connected by a two arm valve (as described for the constant head permeameter): one of the arms was used to purge the air before beginning the test and the other was used to fit the sample using a rubber cap that fitted the sample perfectly. Each tube had its own standpipe connector in order to control the flow individually. On the floor, beneath the permeameter, there was a container to collect the water that had passed through the sample. It is possible to test 8 samples at the same time but it is strongly recommended 

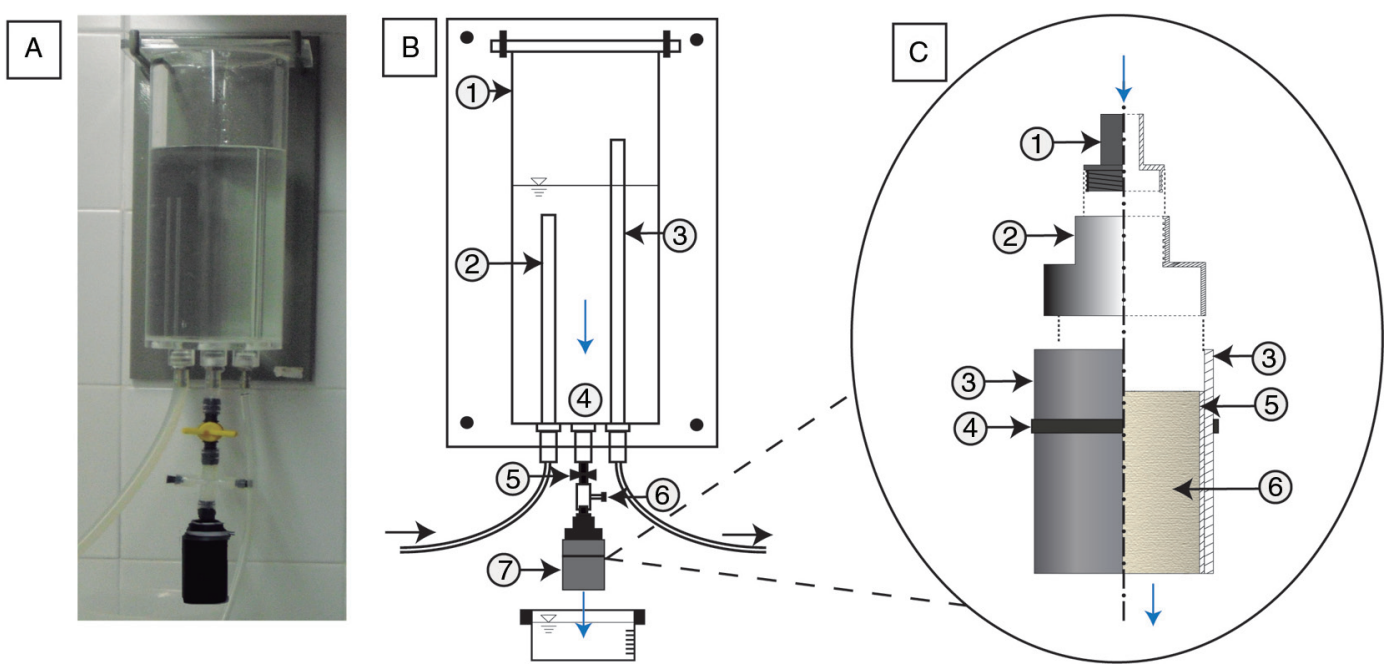

Figure 3. Constant head permeameter: (A). Constant head apparatus. (B). Schematic diagram: 1. Tank with over flow. 2. Inflow water. 3. Outflow water. 4. Water exit to the sample. 5. Valve to fit the sample. 6. Valve to purge the sample. 7. Sample. (C). Sample preparation: 1. PVC connection cup. 2. PVC screw fitting. 3. Heat shrinkable sleeve. 4. Adjusting flange. 5. PTFE. 6. Sample.
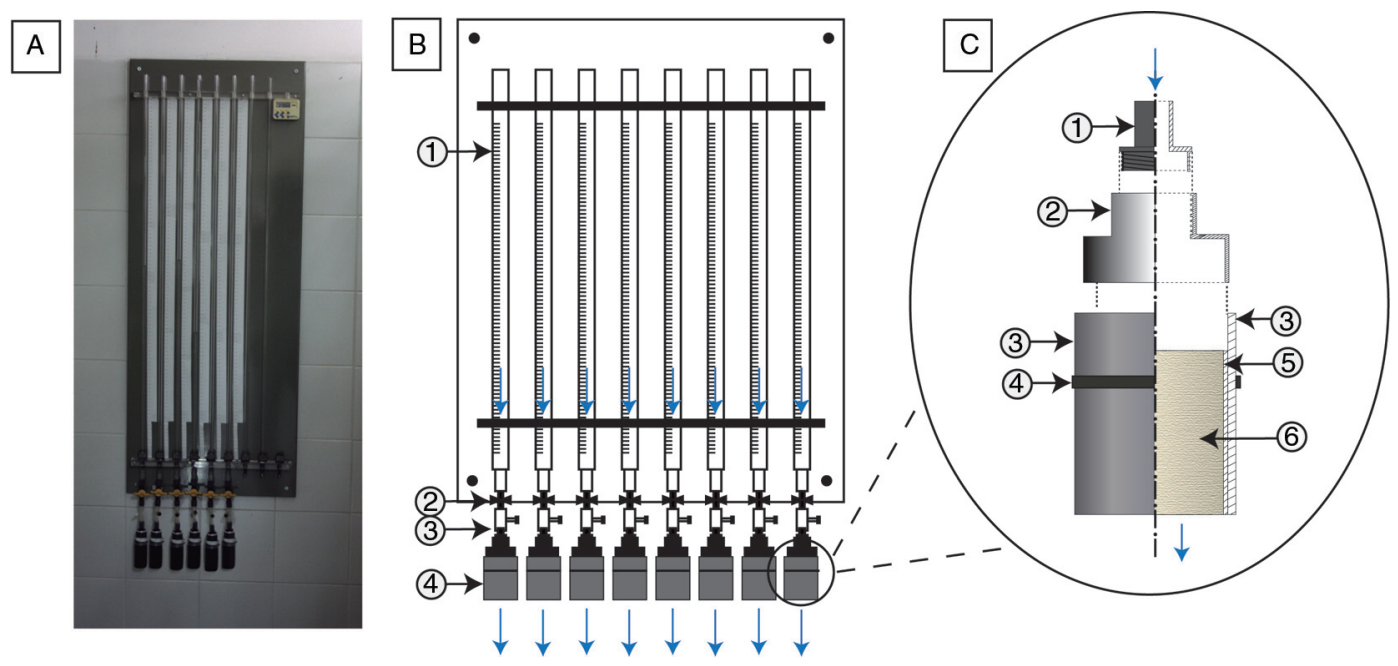

Figure 4. Falling head permeameter ( 8 tubes). (A). Falling head apparatus ( 8 tubes). (B). Schematic diagram: 1. Crystal tube 2. Valve to fit the sample. 3. Valve to purge the sample. 4. Sample. (C). Sample preparation: 1. PVC connection cup. 2. PVC screw fitting. 3. Heat shrinkable sleeve. 4. Adjusting flange. 5. PTFE. 6. Sample.

that the testing of each sample is separated by 2 minutes from the beginning of the previous test. To start the test, the tube was filled with water and air was removed from the column by the standpipe. Once the air had been removed and the water level remained stable the height of water corresponded to time 0 and the experiment could start. The different heights of water are recorded per unit time.

The second method (single graduated cylinder) had a specially made design and consisted of a graduated cylinder thread connected to a PVC cell. This method aims to show a cost-effective solution suited to investigating rock with medium-high permeability values.
The method is easy to perform and adapt to different sample dimensions, and also it is inexpensive, versatile and portable. The used graduated cylinder was in the form of $27 \mathrm{~mm}$ diameter and $235 \mathrm{~mm}$ height. The base of the graduated cylinder was removed and adapted in order to thread it to the PVC cell via a screw fitting. Several rubber joints were used to adapt the height sample to the PVC cell. Both, PVC cell and the screw are typical DIY pieces. In the bottom there was a fitting container to collect the water that flew through the pores of the sample. To obtain water permeability, the tube was filled by water and different heights of water were recorded per unit time. 

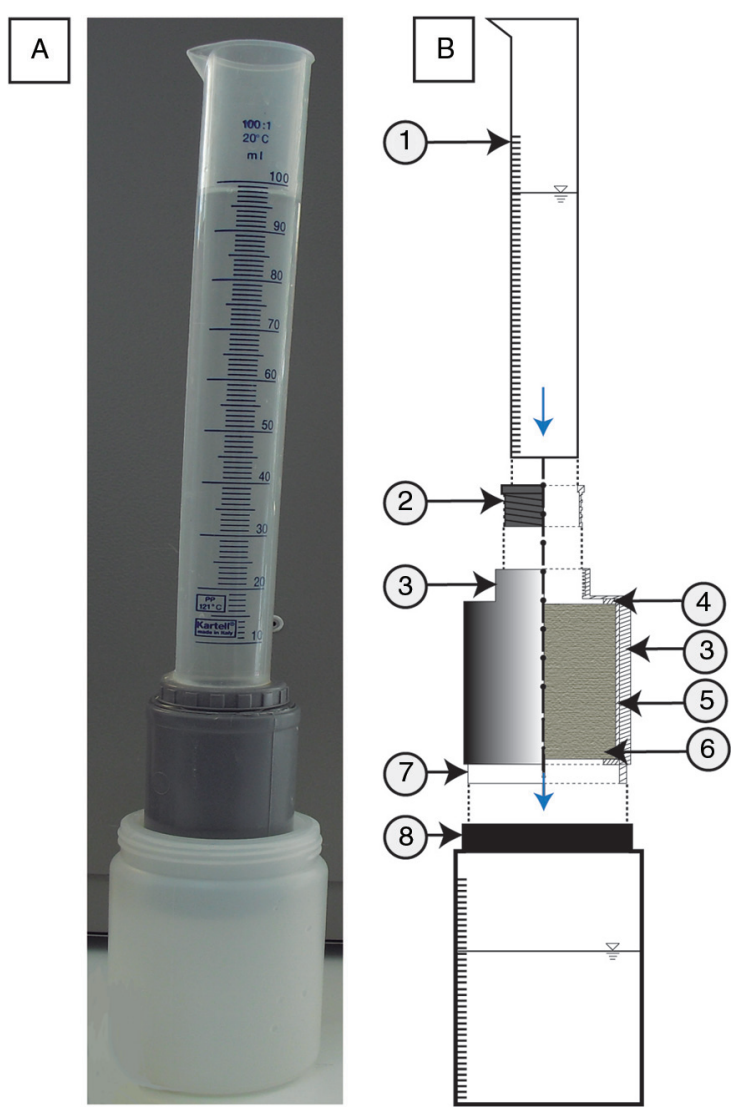

FIGURE 5. Falling head permeameter (Single graduated cylinder). (A). Falling head apparatus. (B). Schematic diagram: 1. Graduated cylinder. 2. PVC screw fitting. 3. PVC cell to house the sample. 4. Rubber joint. 5. PTFE. 6. Sample. 7. End piece to fit the PVC cell into the container. 8. Container to collect the water.

In both methods, samples were laterally sealed with PTFE and a heat shrinkable sleeve using the same methodology performed in the constant head method.

Water permeability or hydraulic conductivity, $\mathrm{k}(\mathrm{m} / \mathrm{s})$, of the sample is calculated using the following equation [3]:

$$
k=\frac{a L}{A t} \ln \left(\frac{h_{o}}{h}\right)
$$

where $a$ is the cross sectional area of the pipe $\left(\mathrm{m}^{2}\right), L$ is the length of the sample (m), $A$ is the cross sectional area of the sample $\left(\mathrm{m}^{2}\right)$, and $t$ is the time (s) taken for head fall from initial head $h_{0}$ to final head $h(\mathrm{~m})$.

\section{RESULTS AND DISCUSSION}

Table 1 shows the wide permeability values of tested rocks obtained with the different water permeability methods. These values range from $10^{-12}$ to $10^{-4} \mathrm{~m} / \mathrm{s}\left(\sim 10^{-19}-10^{-11} \mathrm{~m}^{2}\right.$ or $\left.\sim 10^{-4}-10^{4} \mathrm{mD}\right)$.
The Hölting classification for the permeability (26) classifies stones into 4 groups: very low permeable with a $\mathrm{k}$ value under $10^{-8} \mathrm{~m} / \mathrm{s}$; low permeable for $10^{-6}$ $<\mathrm{k}<10^{-8} \mathrm{~m} / \mathrm{s}$; permeable for $10^{-4}<\mathrm{k}<10^{-6} \mathrm{~m} / \mathrm{s}$; and high permeable for values of $\mathrm{k}$ higher than $10^{-4} \mathrm{~m} / \mathrm{s}$.

Considering results from the TM, eight varieties of the studied building stones $(\mathrm{C} 1, \mathrm{C} 2, \mathrm{C} 4, \mathrm{C} 6, \mathrm{~T} 7$, T8, T9, L12) are classified as very low permeability rocks, other six (C3, C5, L12, L14, S16, S17) are low permeable and the last three (L10, L11, L15) are permeable.

For very low permeable samples, in general, water permeability values obtained with TM present similar or slightly higher values than those MTM and similar or slightly lower than falling head method. However, we did not acquire reproducible values using the constant head method for 24 hours of testing. This could be improved by increasing the height of the water column and/or the test duration. Figure 6 displays different abacuses that were plotted by applying Eq. [3]. These abacuses show different experimental parameters (height and diameter of the water column, testing time and size sample) that can be modified to reach the given permeability value. Thus, permeable materials should be characterised using wide samples and/or water columns. The ratio length/diameter of sample, which is reflected on the Eq. [3], is also important for optimizing testing times. Wide samples (high values of height) contribute to obtain accurate values of permeability, although the testing times tend to be considerably increased. Wide samples therefore are more appropriated to characterise permeable materials whereas thin samples (low values of height) are suitable to measure permeability in low permeable materials.

For low permeability samples $\left(10^{-6}<\mathrm{k}<10^{-8} \mathrm{~m} / \mathrm{s}\right)$, in general, water permeability values obtained with TM and MTM methods present similar values and they are slightly higher values than those obtained from constant and falling head methods. Most samples can be tested using all the studied methods. Samples C5, L13 and S17 showed the most dispersed results between the different tested methods.

The permeable building rocks (L9, L10 and L15) showed comparable values in the tested permeability methods. For this kind of permeable materials, MTM method cannot be used, and therefore recommended, since equipment cannot reach the inflow pressure due to the fast water flow through the porous rock. This problem is also found for the TM in high permeable materials, so that, both constant and falling head methods are highly recommended for permeable and high permeable porous building materials.

The two variations of falling head methods studied in this paper provide, in general, comparable values. However, the measurement of the water height 
TABLE 1. Effective porosity, $\mathrm{O}_{\mathrm{vs}}$, and water permeability obtained using different methods: triaxial (TM), modified triaxial (MTM), constant head and falling head. (-) Non-reproducible values using the experimental conditions of this study. Samples are classified (Hölting classification) into 3 groups considering results from de TM

\begin{tabular}{|c|c|c|c|c|c|c|c|c|c|c|}
\hline \multirow[b]{2}{*}{ Sample } & \multirow{2}{*}{$\begin{array}{c}\text { Effective } \\
\text { porosity, } \\
\text { p }(\%)\end{array}$} & \multicolumn{4}{|c|}{$\begin{array}{c}\text { Water permeability or hydraulic } \\
\text { conductivity, } \mathrm{k}(\mathrm{m} / \mathrm{s})\end{array}$} & \multicolumn{4}{|c|}{$\begin{array}{c}\text { Water permeability or intrinsic } \\
\text { permeability, } \mathbf{k}\left(\mathbf{m}^{2}\right)\end{array}$} & \multirow{2}{*}{$\begin{array}{c}\text { Hölting } \\
\text { Permeability } \\
\text { Classification }\end{array}$} \\
\hline & & TM & MTM & $\begin{array}{l}\text { Constant } \\
\text { Head }\end{array}$ & $\begin{array}{l}\text { Falling } \\
\text { Head }\end{array}$ & TM & МТM & $\begin{array}{l}\text { Constant } \\
\text { Head }\end{array}$ & $\begin{array}{l}\text { Falling } \\
\text { Head }\end{array}$ & \\
\hline $\mathrm{C} 1$ & 3.87 & $2.10 \mathrm{E}-11$ & $5.20 \mathrm{E}-10$ & - & $6.20 \mathrm{E}-10$ & $2.10 \mathrm{E}-18$ & $5.20 \mathrm{E}-17$ & - & $6.20 \mathrm{E}-17$ & \multirow{8}{*}{$\begin{array}{l}\text { Very low } \\
\text { permeable }\end{array}$} \\
\hline $\mathrm{T} 7$ & 7.04 & $1.00 \mathrm{E}-10$ & $1.40 \mathrm{E}-10$ & - & 2.30E-09 & $1.00 \mathrm{E}-17$ & $1.40 \mathrm{E}-17$ & - & $2.30 \mathrm{E}-16$ & \\
\hline T8 & 12.54 & $1.00 \mathrm{E}-10$ & $6.30 \mathrm{E}-12$ & - & $6.00 \mathrm{E}-10$ & $1.00 \mathrm{E}-17$ & $6.30 \mathrm{E}-19$ & - & $6.00 \mathrm{E}-17$ & \\
\hline $\mathrm{C} 4$ & 16.70 & $1.06 \mathrm{E}-10$ & $1.20 \mathrm{E}-09$ & - & $3.09 \mathrm{E}-10$ & $1.06 \mathrm{E}-17$ & $1.20 \mathrm{E}-16$ & - & $3.09 \mathrm{E}-17$ & \\
\hline L12 & 8.62 & $5.10 \mathrm{E}-10$ & $7.00 \mathrm{E}-10$ & - & 2.10E-09 & $5.10 \mathrm{E}-17$ & $7.00 \mathrm{E}-17$ & - & $2.10 \mathrm{E}-16$ & \\
\hline T9 & 8.46 & $9.00 \mathrm{E}-10$ & $6.00 \mathrm{E}-10$ & - & $1.00 \mathrm{E}-09$ & $9.00 \mathrm{E}-17$ & $6.00 \mathrm{E}-17$ & - & $1.00 \mathrm{E}-16$ & \\
\hline $\mathrm{C} 2$ & 20.61 & $2.26 \mathrm{E}-09$ & $1.60 \mathrm{E}-09$ & - & $6.90 \mathrm{E}-09$ & $2.26 \mathrm{E}-16$ & $1.60 \mathrm{E}-16$ & - & $6.90 \mathrm{E}-16$ & \\
\hline C6 & 26.71 & 8.39E-09 & 2.47E-08 & - & 5.10E-09 & $8.39 \mathrm{E}-16$ & $2.47 \mathrm{E}-15$ & - & $5.10 \mathrm{E}-16$ & \\
\hline L14 & 11.99 & $1.09 \mathrm{E}-08$ & $1.77 \mathrm{E}-08$ & - & $1.09 \mathrm{E}-08$ & $1.09 \mathrm{E}-15$ & $1.77 \mathrm{E}-15$ & - & $1.09 \mathrm{E}-15$ & \multirow{6}{*}{ Low permeable } \\
\hline S16 & 13.10 & $2.02 \mathrm{E}-08$ & $3.30 \mathrm{E}-08$ & - & 2.70E-09 & $2.02 \mathrm{E}-15$ & $3.30 \mathrm{E}-15$ & - & $2.70 \mathrm{E}-16$ & \\
\hline $\mathrm{C} 3$ & 22.02 & $6.27 \mathrm{E}-08$ & 5.33E-08 & $1.06 \mathrm{E}-08$ & $1.41 \mathrm{E}-08$ & $6.27 \mathrm{E}-15$ & $5.33 \mathrm{E}-15$ & $1.06 \mathrm{E}-15$ & $1.41 \mathrm{E}-15$ & \\
\hline L13 & 22.05 & $8.32 \mathrm{E}-08$ & 5.38E-08 & $8.70 \mathrm{E}-09$ & $2.47 \mathrm{E}-08$ & $8.32 \mathrm{E}-15$ & $5.38 \mathrm{E}-15$ & $8.70 \mathrm{E}-16$ & $2.47 \mathrm{E}-15$ & \\
\hline S17 & 16.05 & $1.05 \mathrm{E}-07$ & $3.60 \mathrm{E}-08$ & $9.90 \mathrm{E}-09$ & $1.45 \mathrm{E}-08$ & $1.05 \mathrm{E}-14$ & $3.60 \mathrm{E}-15$ & $9.90 \mathrm{E}-16$ & $1.45 \mathrm{E}-15$ & \\
\hline $\mathrm{C} 5$ & 23.56 & $1.06 \mathrm{E}-07$ & $2.55 \mathrm{E}-08$ & - & 4.50E-09 & $1.06 \mathrm{E}-14$ & $2.55 \mathrm{E}-15$ & - & $4.50 \mathrm{E}-16$ & \\
\hline L15 & 18.87 & $2.28 \mathrm{E}-06$ & - & $1.35 \mathrm{E}-07$ & $8.80 \mathrm{E}-07$ & $2.28 \mathrm{E}-13$ & - & $1.35 \mathrm{E}-14$ & $8.80 \mathrm{E}-14$ & \multirow{3}{*}{ Permeable } \\
\hline L10 & 20.35 & $2.93 \mathrm{E}-06$ & - & $2.75 \mathrm{E}-06$ & $7.72 \mathrm{E}-06$ & $2.93 \mathrm{E}-13$ & - & $2.75 \mathrm{E}-13$ & $7.72 \mathrm{E}-13$ & \\
\hline L11 & 19.01 & $1.25 \mathrm{E}-05$ & - & $6.36 \mathrm{E}-06$ & $1.09 \mathrm{E}-05$ & $1.25 \mathrm{E}-12$ & - & $6.36 \mathrm{E}-13$ & $1.09 \mathrm{E}-12$ & \\
\hline
\end{tabular}

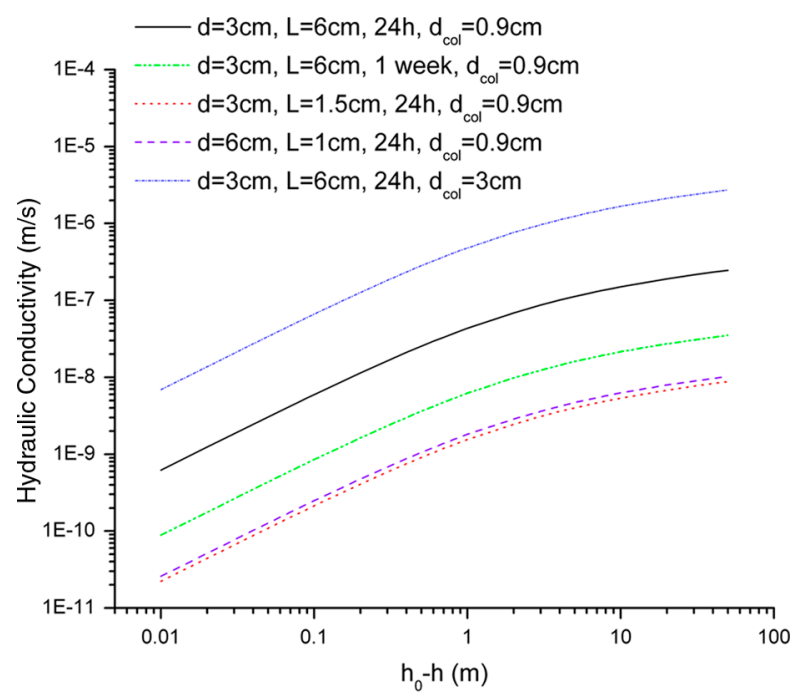

FIGURE 6. Hydraulic conductivity abacuses for the falling head method. Experimental parameters: height and diameter, $\mathrm{d}_{\mathrm{col}}$, of the water column, testing time and size (diameter, $\mathrm{d}$, and length, $\mathrm{L}$ ) of the sample for the height variation from initial head, h0, to final head, $\mathrm{h}$

variation in the graduated cylinder is not as satisfactory as in the falling head-8 tubes method, and therefore, does not provide accurate results. For that reason, Table 1 only lists the values acquired with the falling head- 8 tubes method. Table 2 summarizes the appropriate water permeability ranges for the tested permeability methods.

The classical permeability - porosity relationship based in Lucia's classification is showed in Figure 7 (see details in (27)). Lucia developed an interesting classification for carbonate sedimentary rocks to understand the influence of each type of porosity on permeability. The permeability of rocks is only related to its porosity when they have similar type of pores and similar pore size. Figure 7 displays the Hölting classification and a modified Lucia's plot, which defines permeability fields of rocks with visible interparticle pores at hand specimen. Thus, building rocks with large interparticle pores (pores visible at first glance) and high values of effective porosity present high water permeability values. The studied travertine samples present separated and touching vugs. Thus, on the one hand, T8 presents separated vugs that contribute to porosity but not to water permeability. On the other hand, T9 has both separated and touching vugs, and therefore shows a water permeability value higher than the other travertines.

Encouraging results were obtained using nonsaturated samples. The MTM was used for several very low permeable and low permeable samples whereas the falling head method was applied to 
TABLE 2. Ranges of water permeability for each tested method.

\begin{tabular}{lcc}
\hline Test method & Hydraulic conductivity $(\mathrm{m} / \mathbf{s})$ & Intrinsic permeability $\left(\mathbf{m}^{2}\right)$ \\
\hline Triaxial & $10^{-11}<\mathrm{k}<10^{-5}$ & $10^{-18}<\mathrm{k}<10^{-12}$ \\
Modified triaxial method & $10^{-9}<\mathrm{k}<10^{-7}$ & $10^{-16}<\mathrm{k}<10^{-4}$ \\
Constant head permeameter & $\mathrm{k}>5.10^{-8}$ & $\mathrm{k}>5.10^{-15}$ \\
Falling head permeameter & $10^{-10}<\mathrm{k}<10^{-6}$ & $1^{-17}<\mathrm{k}<10^{-13}$ \\
\hline
\end{tabular}

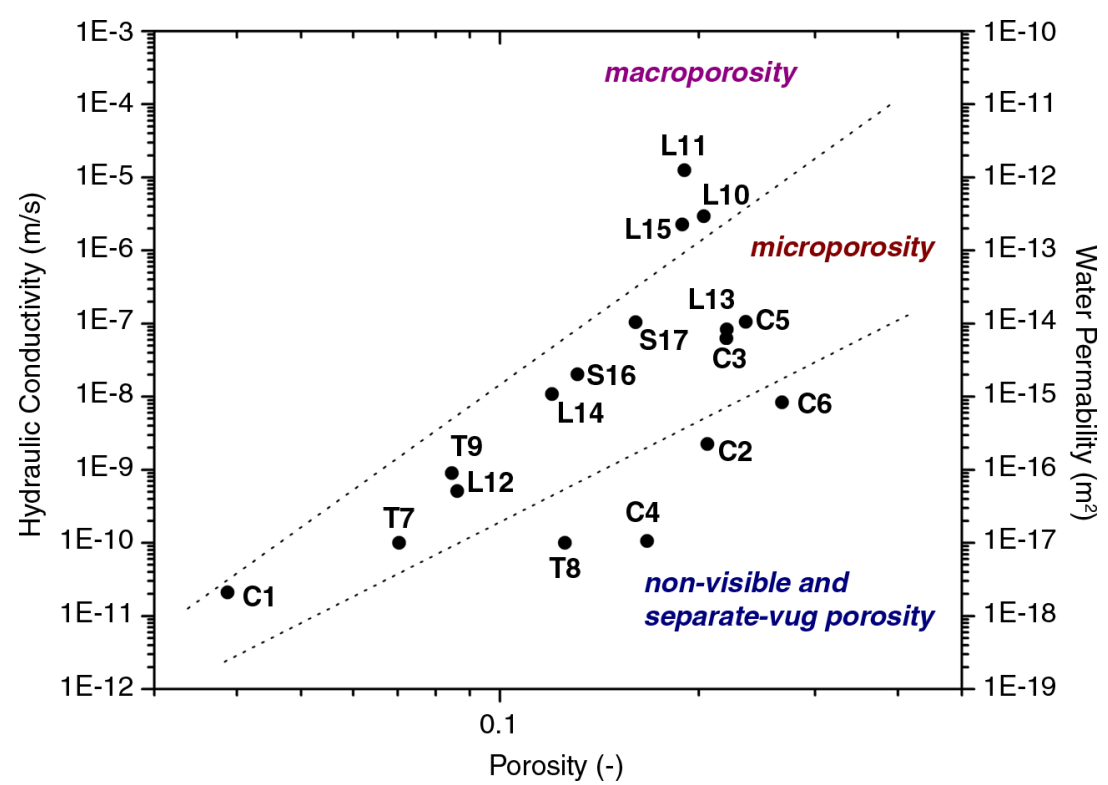

FIGURE 7. Permeability - porosity relationship based in the Lucia's classification of the studied porous building rocks. Horizontal divisions correspond to Hölting classification.

several low permeable and permeable samples. Water permeability values obtained using MTM method of the samples $\mathrm{C} 2, \mathrm{C} 3, \mathrm{C} 4, \mathrm{C} 5$ and Q7 were, respectively, $1.57 \cdot 10^{-9}, 5.52 \cdot 10^{-8}, 7.10 \cdot 10^{-10}, 9.43 \cdot 10^{-8}$ and $1.73 \cdot 10^{-8} \mathrm{~m} / \mathrm{s}$; whereas using falling head method characterisation of the samples C3, Q7, L9 and L10 were $3.49 \cdot 10^{-8}, 3.70 \cdot 10^{-8}, 4.68 \cdot 10^{-4}$, and $3.74 \cdot 10^{-5} \mathrm{~m} / \mathrm{s}$. Consequently, for low permeable and permeable samples, satisfactory water permeability values can be obtained in non-saturated samples when steady-state is reached. Moreover, from the practical point of view, the permeameter cell of the falling head method can test samples with different sizes and forms, such as prismatic forms (28). These qualities suggest confidence to the falling head method as the most appropriated test for characterizing soft samples.

\section{CONCLUSIONS}

In this paper, different laboratory methods have been employed and adapted from standard tests used in cementitious materials and soil sciences field. Seventeen porous rocks have been chosen for their different petrophysical and petrographic characteristics, which are used as building materials or found in the Spanish built heritage. The characterisation of rock permeability and hydraulic conductivity, $\mathrm{k}$, was carried out in the range of $10^{-12}$ to $10^{-4} \mathrm{~m} / \mathrm{s}\left(\sim 10^{-19}-10^{-11} \mathrm{~m}^{2}\right.$ or $\left.\sim 10^{-4}-10^{4} \mathrm{mD}\right)$.

Table 2 summarizes the water permeability ranges most appropriated for each tested permeability method. Thus, for very low $\left(\mathrm{k}<10^{-8} \mathrm{~m} / \mathrm{s}\right)$ and low permeable samples $\left(10^{-6}<\mathrm{k}<10^{-8} \mathrm{~m} / \mathrm{s}\right)$, triaxial methods were found the most accurate procedures and they provided similar or slightly lower permeability values than falling and head methods. On the other, both constant and falling head methods are highly recommended for permeable $\left(10^{-4}<\mathrm{k}<10^{-6} \mathrm{~m} / \mathrm{s}\right)$ and high permeable $\left(\mathrm{k}>10^{-4} \mathrm{~m} / \mathrm{s}\right)$ porous building materials.

The maximum duration of each experiment was 24 hours in order to assess what method was more adequate for relatively fast permeability characterisations. In order to achieve the most appropriated combination of experimental parameters for a given 
rock permeability, different abacuses were plotted, in which height and diameter of the water column, testing time and sample size can be changed.

A modified Lucia's plot defined permeability fields of rocks with visible interparticle pores at hand specimen. Rock specimens with large interparticle pores (pores visible at first glance) and high values of effective porosity present high water permeability values. In particular, travertine T8 shows separated vugs that contribute to porosity but not to water permeability whereas T9 has both separated and touching vugs, and therefore shows a water permeability value higher than the other travertines.

Finally, some modifications of the apparatus and procedures were carried out using non-saturated samples in order to assess water permeability in soft materials, such as soft rocks, ancient and repair mortars. The modified triaxial method was found to be the most appropiated procedure for several very low permeable and low permeable samples, whereas falling head method for several low permeable and permeable samples.

\section{ACKNOWLEDGEMENTS}

This study was financed by the Spanish Ministry of Science and Innovation CGL2011-25162. A predoctoral research fellowship was awarded to C. Pla for this project.

\section{REFERENCES}

1. Hall, C.; Hoff, W.D. (2002) Water transport in brick, stone and concrete, p. 336, Spon Press. London. http://dx.doi. org/10.4324/9780203301708.

2. Winkler, E.M. (1997) Stone in architecture: properties, durability, p. 327 Springer-Berlin-Heidelberg. New York. http:// dx.doi.org/10.1007/978-3-662-10070-7.

3. Fornaro, M.; Lovera, E. (2004) Engineering geology for infrastructure planning in Europe. In: Lecture Notes in Earth Sciencies. Springer-Berlin-Heidelberg. 104, 574-584.

4. Valcuende, M.O.; Parra, C.; Benlloch, J. (2005) Permeability, porosity and compressive strength of self-compacting concrete. Mater. Construcc., 55, [280], 17-26. http://dx.doi. org/10.3989/mc.2005.v55.i280.203.

5. Bermejo, E.B.; Moragues, A.; Gálvez, J.C.; Fernández, M. (2010) Permeability and pore size distribution in medium strength self-compacting concrete. Mater. Construcc., 60, [299], 37-51. http://dx.doi.org/10.3989/mc.2010.50709.

6. Fitzner, B.; Heinrichs, K.; La Bouchardiere, D. (2004) The Bangudae Petroglyph in Ulsan, Korea: studies on weathering damage and risk prognosis. Environ. Geol., 46, 504-526. http://dx.doi.org/10.1007/s00254-004-1052-x.

7. Siegesmund, S.; Snethlage, R. (Eds) (2011) Stone in Architecture: Properties, Durability, p. 552, Springer-Verlag, Berlin. http://dx.doi.org/10.1007/978-3-642-14475-2.

8. Benavente, D; Cueto, N.; Martínez-Martínez, J.; Garcíadel-Cura, M.A.; Cañaveras, J.C. (2007) Influence of petrophysical properties on the salt weathering of porous building rocks. Environ. Geol., 52, 197-206. http://dx.doi. org/10.1007/s00254-006-0475-y.

9. Benavente, D. (2011) Why Pore Size Is Important in the Deterioration of Porous Stones Used in the Built Heritage. Macla, 15, 41-42.

10. McCabe, S.; McKinley, J. M.; Gómez-Heras, M. (2011) Dynamical instability in surface permeability characteristics of building sandstones in response to salt accumulation over time. Geomorphology., 130, 65-75. http://dx.doi. org/10.1016/j.geomorph.2010.10.006.

11. McKinley, J. M.; McCabe, S. (2010) A Geostatistical Investigation into Changing Permeability of Sandstones During Weathering Simulations. Geographical Analysis., 42, 180-203. http://dx.doi.org/10.1111/j.1538-4632.2010. 00789.x.

12. ASTM D4525-90 (1990) Standard: Standard Test Method for Permeability of Rocks by Flowing Air. Anual Book of ASTM standards, vol. 04.08 (Soil and Rocks).

13. ASTM D6035-02 (2002) Standard: Standard Test Method for Determining the Effect of Freeze-Thaw on Hydraulic Conductivity of Compacted or Undisturbed Soil Specimens Using a Flexible Wall Permeameter. ANNUAL BOOK OF ASTM STANDARS, vol. 04.09 (Soil and Rock).

14. ASTM D6527-00 (2000) Standard: Standard Test Method for Determining Unsaturated and Saturated Hydraulic Conductivity in Porous Media by SteadyState Centrifugation. ANNUAL BOOK OF ASTM STANDARS, vol. 04.09 (Soil and Rock).

15. UNE 103403 (1999) Determinación de la permeabilidad de una muestra de suelo. Método de carga constante.

16. UNE 83310 (1990) Ensayos de hormigón. Determinación de la permeabilidad.

17. RILEM (1980) Tentative recomendations issued by 13-mr committee of mortars and rederinf. Vol 13 (1980), no 73-78.

18. ASTM 5856-95 (1995) Standard: Standard Test Method for Measurement of Hydraulic Conductivity of Porous Material Using a Rigid-Wall, Compaction-Mold Permeameter. ANNUAL BOOK OF ASTM STANDARS, vol. 04.09 (Soil and Rock).

19. Campos, M.J. (2003) La piedra Dorada en Úbeda y Baeza. Caracterización y procesos de alteración". PhD Thesis. Universidad de Jaén, Departamento de Geología.

20. Benavente, D. (2003) Modelización y estimación de la durabilidad de materiales pétreos porosos frente a la cristalización de sales. $P h D$ Thesis, Universidad de Alicante. Biblioteca Virtual Miguel de Cervantes: http:// www.cervantesvirtual.com/FichaObra.html?Ref $=12011$ (Accessed:10/07/2013)

21. Benavente, D.; García-del-Cura, M.A.; Fort, R.; Ordóñez, S. (2004) Durability estimation of porous building stones from pore structure and strength. Eng. Geol., 74, 113-127. http://dx.doi.org/10.1016/j.enggeo.2004.03.005.

22. Benavente, D.; Cultrone, G.; Gómez-Heras, M. (2008) The combined influence of mineralogy, hydric and thermal properties in the durability of porous building stones. Eur. J. Min., 20, 673-685. http://dx.doi.org/10.1127/0935$1221 / 2008 / 0020-1850$.

23. García-del-Cura, M.A.; Benavente, D.; MartinezMartinez, J.; Cueto, N. (2012) Sedimentary structures and physical properties in travertine and carbonate tufa building Stone. Const. Build. Mat., 28, 456-467. http://dx.doi. org/10.1016/j.conbuildmat.2011.08.042.

24. Martínez-Martínez, J.; Benavente, D.; Gómez-Heras, M.; Marco-Castaño, L.; García-del-Cura, M. (2013) Nonlinear decay of building stones during freeze-thaw weathering processes. Const. Build. Mat., 38, 443-454. http:// dx.doi.org/10.1016/j.conbuildmat.2012.07.059.

25. Cueto, N.; Benavente, D.; Martínez-Martínez, J.; Garcíadel-Cura MA. (2009) Influence of mesofabric on water transport properties of continental limestones. In proceeding of: IX ASMOSIA (Association for the Study of Marbles and other Stones in Antiquity) International Conference, 181, Tarragona (Spain).

26. Hölting, B. (1989) Hydrogeology. An introduction to general and applied hydrogeology., p. 226, F. Enke Publ., Stuttgart

27. Lucia, FJ. (2007) Carbonate reservoir characterization: an integrated approach., Springer, USA.

28. Arizzi, A.; Cultrone, G. (2013) The water transfer properties and drying shrinkage of aerial lime-based mortars: an assessment of their quality as repair rendering materials. Environ. Earth. Sci., 1-12. http://dx.doi.org/10.1007/ s12665-013-2574-X. 